\title{
THE OPINION OF FOREST OWNERS ON EUROPEAN UNION SUBSIDIES INTENDED FOR FOREST MANAGEMENT IN LATVIA
}

\begin{abstract}
Raimonds BĒRMANIS, Faculty of Forestry, University of Life Sciences and Technologies, Latvia, Akademijas iela 11, Jelgava, Latvia, raimonds.bermanis@ mkpc.llkc.lv

Inga STRAUPE, Faculty of Forestry, University of Life Sciences and Technologies, Latvia, Alademijas iela 11, Jelgava, Latvia, email inga.straupe@llu.lv (corresponding author)

Andra ZVIRBULE, Faculty of Economics and Social Development, University of Life Sciences and Technologies, Latvia, Svētes iela 18, Jelgava, Latvia, e-mail andra.zvirbule@llu.lv

To clarify the opinion of Latvian private forest owners on the use of EU funding in forest management, a survey of forest owners (Latvia University of Life Sciences and Technologies grant project No. Z7 funding) was conducted in November 2018 by the staff members of the Forest Advisory Service Centre (FASC) which is a branch of the Latvian Rural Advisory and Training Centre. A total of 153 forest owners have been included in the survey, of whom 107 (70\%) forest owners have previously used EU funding support in forest management, and 46 forest owners (30\%) who have not used this opportunity. The respondents included in the survey represent forest owners from all regions of Latvia. The survey included general questions describing the profile of the forest owner, such as the size of the owned forest area, for how long the forest has been the owner's property, knowledge of forest management and the way of receiving information. Regarding the attracting of EU funding, the forest owner's view of the already used EU support and its type was clarified and the overall level of satisfaction, the necessary improvements, and the type of EU support needed for further forest management were identified. The study also includes the results of other similar surveys carried out by other institutions on forest owners' opinions on EU support for forestry. The results of the survey conducted by FASC confirm that $76 \%$ of forest owners who have already used some measures of the EU's financial support at least once are ready to take advantage of the opportunity to apply for the support also in the future. The forest owners, who have not used EU financial support for forest management so far, continue to express sceptical opinions, and only $46 \%$ of such respondents would be willing to apply for further EU support funding. When comparing the priority support directions specified by forest owners, it can be concluded that the trends in the need for subsidies are fairly similar, $80 \%$ of owners who have previously used the financial EU support, point out that support for young stand and advanced growth thinning is still needed in the future. The same opinion has been expressed by $70 \%$ of forest owners who have not previously used the EU funding. In a series of studies, a general trend for priority of most desirable EU subsidies have been identified and it was revealed that $61 \%$ of forest owners want to receive support for young stand and advanced growth thinning. Half of this percentage of respondents have pointed out the need for EU subsidies for forest amelioration and road construction (32\%), forest establishment (31\%), forest regeneration (30\%) and for compensations of the protection of natural values and for it management $(29 \%)$.
\end{abstract}

Keywords: EU subsidies for forestry, opinion of forest owners, private forestry.

\section{INTRODUCTION}

Upon Latvia's accession to the European Union in 2004, forest owners also had access to funding for support measures under the Rural Development Program, which also provides support for forestry. Initially, since 2008, forest owners have been passive in accessing funding, but by improving application conditions and informing forest owners of this opportunity, forest owners' interest in obtaining subsidies increased rapidly (Ministry of Agriculture, Facts and Figures, 2018), resulting in funding shortages for certain measures, e.g. for pre-commercial thinning of young stands and afforestation (Institure of Agricultural resources and economics, 2017, Benga, 2016). The scope and character of forestry measures in the Rural Development Program (hereinafter RDP) 2014-2020 has increased and also changed compared to the RDP 2007-2013 period (Ministry of Agriculture, RDP 2015, 2019). Forest owners have accumulated more than ten years of experience in applying for and implementing measures, and are already able to compare the conditions of measures from both RDP periods, and can make suggestions for the practical improvement of the conditions of measures.

Taking into account the fact that there were 113561 forest owners in Latvia in 2018 (Donis, 2018), according to the data of Rural Support Service, payment has been made for 3278 forest owners for support on direct forestry activities in the RDP 2014-2020 up to January 2018, which is only $2.9 \%$ of all forest owners. Analyzing the data obtained from forest owners' surveys, there is an increasing willingness of forest owners to apply for EU support, and this is particularly the case of forest owners who have already utilised EU support and so have gained positive experience. However, studies in the UK in 2008 revealed that more than $50 \%$ of non-commercial forest owners who did not receive government financial subsidies felt that such incentives were irrelevant, and more than $30 \%$ of those who received subsidies, admitted that they did not influence their decisions. Research data also show that forest owners from Western European countries (France, Portugal, Slovenia) perceive forest management as a source of subsidies less than forest owners in the Eastern European region (Slovakia, Czech Republic, Romania) (Quiroga, 2018). According to the forest owner's survey

Copyright $\odot 2019$ The Authors. Published by Vytautas Magnus University. This is an open-access article distributed under the terms of the Creative Commons Attribution License (CC BY 4.0), which permits unrestricted use, distribution, and reproduction in any medium, provided the original author and source are credited. 
conducted by Donis in 2018, 24\% of forest owners in Latvia had used EU support for their forest management and $41 \%$ of forest owners plan to do so in the future.

Currently, in 2019 an active discussion has begun on the available forestry support measures for the next RDP period 2021-2027, therefore it is essential to clarify forest owners' opinions on the process of granting EU support for forestry so far, what would the preferred support measures be and what obstacles exist for the owners to apply for EU support, which is also the purpose of this study.

\section{RESEARCH METHODS}

Several surveys and studies have been carried out over the years to ascertain the opinions of private forest owners on the use of EU funding, e.g. as component in monitoring of private forest management and forest property consolidation and cooperation process, what is conducted once per two years. By comparing the results of the research, the main trends in forest owners' opinions and their changes over time have been identified. The main source of the research is the forest owner's survey (Latvia University of Life Sciences and Tehnologies grant Project No. Z7 funding) conducted in November 2018 by the Forest Advisory Service Centre which is a branch of the Latvian Rural Advisory and Training Center (hereinafter FASC survey) and a questionnaire survey of forest owners conducted at the Forest Sector Conference 2018, receiving the opinions from 46 respondents. This research also included relevant information from the forest owner's surveys conducted by the Latvian State Forest Research Institute "Silava" "Monitoring of Private Forest Management and Forest Property Consolidation and Cooperation Process" (Donis, 2014 and 2018) and the study "Potential Contribution of Private Forests to Latvian Wood Industry 2011-2015 annual evaluation" (Jansons, 2010).

A total of 153 forest owners were surveyed in the FASC survey, of which 107 forest owners had used EU funds for forest management and 46 forest owners had not used this opportunity. The survey contained 22 questions and the following requirements had to be fulfilled for the survey:

1) respondents are forest owners - individuals or legal persons,

2) he group of respondents who have used EU support for forest management or the group of respondents who have not used EU support for forest management is at least $20 \%$ of the total number of respondents to the survey;

3) respondents represent forest owners in five defined classes of property area, as property area of up to 10 ha; 10 to $20 \mathrm{ha} ; 20$ to $50 \mathrm{ha}, 50$ to 200 ha and more than $200 \mathrm{ha}$;

4) respondents represent forest owners from the capital, regional cities and rural areas;

5) respondents represent forest owners from all (four) regions of the country, representing at least $10 \%$ of the total number of respondents in each region.

At the beginning of the survey, the respondents previous experience of attracting EU support funding was ascertained, but in the further process of the survey the questions were specified for forest owners who had used EU support funding for forestry and who had not used such support. In general, regarding the attracting of EU funding, the forest owner's opinion of the already used EU support and its type was clarified and the overall level of satisfaction, the necessary improvements, and the type of further EU support needed for forest management were identified. Forest owners with no experience in using EU support funding were asked about the reasons for not applying for funding and what types of forestry activities support would be nessesary. The forest owners of both types were also asked general questions about the size of the owned forest area, for how long the forest has been the owners property, knowledge of forest management and the way of receiving information.

Studies on the classification of European private forest owners show that some classifications are based on structural attributes of the forest owner and their property, while other classifications are more focused on forest management objectives and forestry methods aplied. Earlier studies on the classifications of forest owners have been focused on the need to improve the supply of roundwood, but more recently, aspects of ecosystem services have also been included in the classification (Ficko, 2019).

Taking into account that the FASC survey was conducted by Forest Advisory Service Centre staff who inform, advise and train private forest owners on a daily basis, most of the respondents are likely to be in collaboration with the relevant FASC consultant regularly and therefore are better informed compared to average forest owners and they are generally more active in their forest management, including attraction of EU support funding. Data mathematical calculations were performed with Microsoft Excel 2016.

\section{MAIN RESULTS}

According to the results of the FASC survey, 70\% of forest owners had used EU support, but according to the results of the forest owners' survey conducted by the Latvian State Forest Research Institute Silava (Donis, 2018) (hereinafter - LSFRI Silava survey 2018) only $24 \%$ of repondents had used EU support, what is a more objective result, taking into account the work specifics (hosting events promoting EU subsidies for forestry and prepare documentation to apply for subsidies) of the FASC staff as survey executors. Therefore forest owners who collaborate with FASC should have essentially higher probability to apply for EU subsidies compare to others. According to the survey, forest owners who manage forests of 10 ha or more are more actively using EU support. Forest owners with a forest area of less than 10 ha attract EU subsidies in significantly less intensity. It is also noteworthy that not all owners of large forest areas (of more than 200 ha of forest) utilise EU support. Studies in Lithuania (Stanislovaitis, 2015) also show that the most active forest owners are those who manage more than 20 ha of forest area. 
Evaluating the knowledge or education of forest owners, it can be concluded that those forest owners who have applied for EU support have significantly better knowledge of forest management, both through basic education and attending seminars and courses, compared to forest owners who have not used EU support (Figure 1), and who have acquired their knowledge mainly through self-study and daily forest management practice.

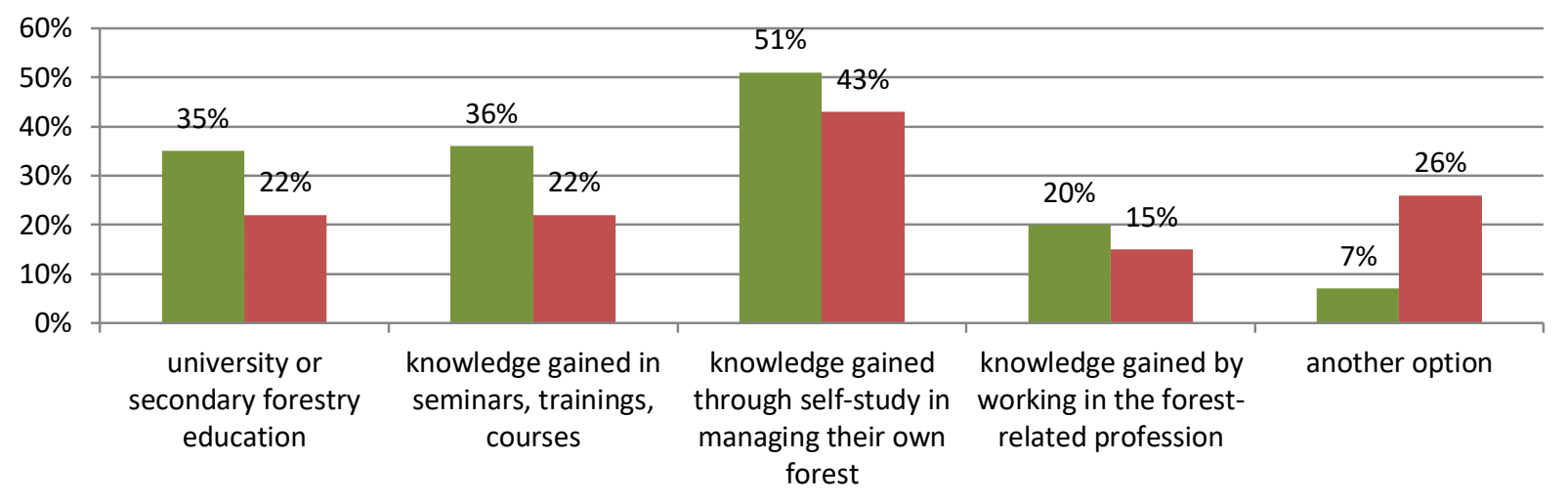

Owners who have used subsidies $\quad$ Owners who have not used subsidies

Figure 1. FASC survey respondents' knowledge of forest management

The results of the LSFRI Silava Survey 2018 (Donis, 2018) show a similar trend, but more forest owners, i. e. 78\%, indicate that they have acquired knowledge through self-study managing their forests. Only $14 \%$ of forest owners reported of having obtained formal forestry education, while $25 \%$ of forest owners have attended seminars or courses.

The results of the FASC survey reveal that in total $99 \%$ of those forest owners who have used EU financial support for their forest management, are satisfied on obtaining of EU support. Of these, $48 \%$ are fully satisfied and $51 \%$ are rather satisfied with receiving the funding. Only $1 \%$ of respondents appeared to be rather dissatisfied with receiving the support funding, what is not further specified.

According to the data of several surveys available, it should be concluded that the number of forest owners who have used and plan to use EU support for their forest management has increased significantly over time. If in the year $2010,29 \%$ of the respondents were ready to use the support, than at the end of the year 2018, the average percentage for both group of forest owners increased to $67 \%$, and additionally $21 \%$ of forest owners are considering this opportunity and are likely to apply for EU support (See Figure 2). According to the results of the LSFRI Silava survey (Donis, 2018), $41 \%$ of forest owners intend to apply for EU support in the future, which is also a significantly higher amount compared to data of 2010 .

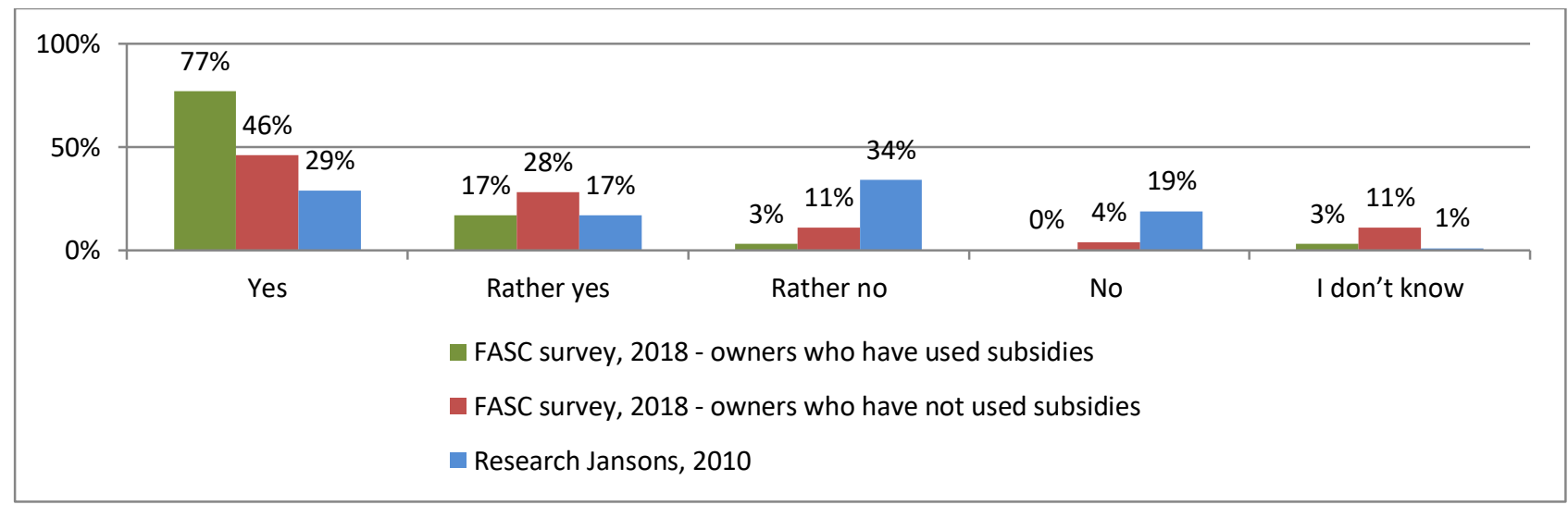

Figure 2. Forest owners' intention to apply for EU support

A general trend has been ascertained for priority support areas where forest owners would like to receive EU financial support. Surveys acknowledge that forest owners are most interested in receiving support for the following activities: thinning of young stands and advanced growth (61\% of respondents), forest drainage and road construction (32\% of respondents), afforestation (31\% of respondents), forest regeneration (30\% of respondents) and compensation for the protection and management of nature values (29\% of respondents). It should be noted that support for the activities mentioned above was available in both RDP periods except for forest regeneration. Subsidies for forest regeneration are granted only in cases where the forest stand is destroyed as a result of natural disaster or to replacing non-productive stands or stands of low productivity.

The results of the surveys on the desirable EU support measures in different years are relatively similar. Of all the surveys conducted, the supports mentioned most often was that for thinning of young stands and advanced growth. The 
authors of other studies (Quiroga, 2018) conclude that forest owners in Eastern Europe consider economic aspects and forest tending and maintenance to be the most important ones, compared to forest owners in industrialized countries, who prefer more subsidies to address environmental and nature conservation issues. The results also highlight the need for EU support for forest drainage and road construction as well as for afforestation. These priorities have been highlighted as most desirable both by forest owners who have previously utilised EU forest management support and by those who have not used this opportunity so far (Figure 3).

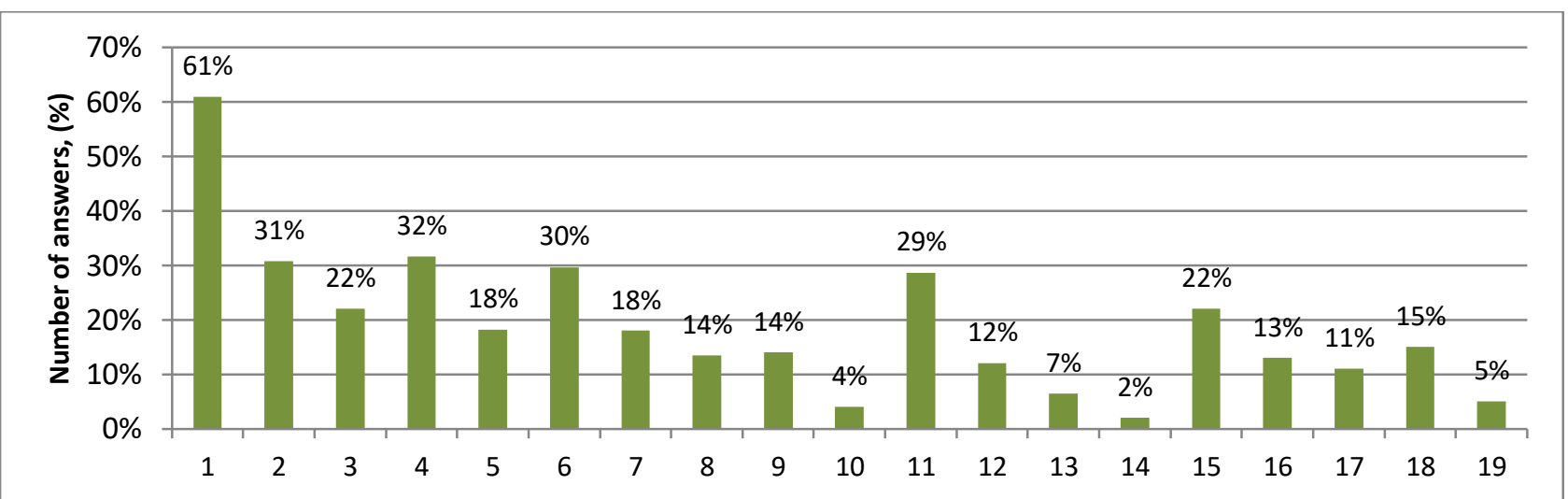

Legend: 1. thinning of young stands and advanced growth; 2. afforestation; 3. purchase of small machinery and motorised tools; 4. forest drainage and roads construction; 5. replacement of low productivity forest stands; 6 . forest regeneration; 7. forest regeneration after natural disasters; 8 . consultations; 9 . protection of young stands from wild animal damages; 10. purchase of large size profesional forest machinery; 11 . compensation for the protection and management of nature values; 12 . improving knowledge, training; 13. development of forest owners cooperatives; 14 . No support required; 15. Support for forest owner's voluntary management methods to enhance forest's social and environmental value, for initial forest certification; 16 . The state credit support for the owners of small and medium-sized forests in purchasing forest land, thus facilitating consolidation; 17. support for young forest owners in overtaking ownership from parents; 18. establishment of fast-growing plant (willows, gray alder) plantation for woodchips; 19. other area / activity.

Figure no. 3. Priority areas where forest owners prefer to have EU financial support (average \% of five surveys)

Comparing the priority directions of support indicated by forest owners, the conclusion is that the tendencies of desirable EU support are similar. 80\% of owners who have previously utilised EU financial support indicate that support for thinning of young stands and advanced growth is still needed. The same opinion has been expressed by $70 \%$ of forest owners who have not used EU support funding so far. Opinions also agree on the necessity for support for afforestation. This is highlighted by 34\% and 35\% respectively of both type of forest owners. Both measures for EU subsidies mentioned above were most desirable for small and medium sized forest owners (forest area up to 50 ha) and also for large forest owners with forest area over 50 ha. Likewise, both research groups related to use of EU subsidies, have identified the purchase of small-scale machinery and motorised tools, forest drainage and road construction and maintenance, and replacement of low productivity forest stands and all these topics were more significant to large forest owners, compare to small and medium sized forest owners. Identifying forest owners using EU support, it has been concluded that they are mainly forest owners with forest education or knowledge obtained during the training process (Figure 2). Furthermore, the forest owners, who have not previously used EU support, much more frequently indicate that they would like to receive the support for obtaining advice, improving knowledge and for training, (Figure 4), and these measures for desirable EU support, in addition of measure to support forest regeneration were more significant to small and medium sized forest owners, compare to large forest owners.

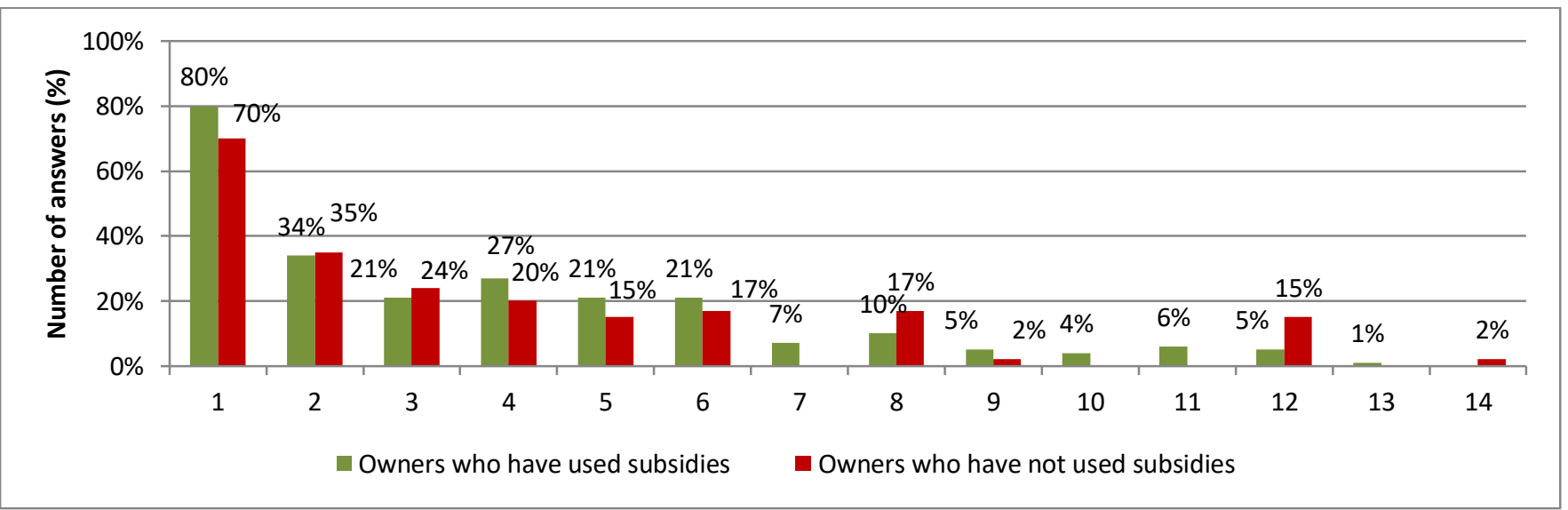

Legend: 1 . thinning of young stands and advanced growth; 2. afforestation; 3. purchase of small machinery and motorised tools; 4 . forest drainage and roads construction; 5. replacement of low productivity forest stands; 6 . forest regeneration; 7. forest regeneration after natural disasters; 8. consultations; 9. protection of young stands from wild animal damages; 10. purchase of large size profesional forest machinery; 11 . compensation for the protection and management of nature values; 12. improving knowledge, training; 13. development of forest owners cooperatives; 14 . No sup port required.

Figure 4. Priority areas where forest owners prefer to have EU financial support 
EU subsidies for forest regeneration as desirable measures were indicated by $10 \%$ (4th most chosen) of small and medium sized forest owners, while large forest owners didn't mention this type of subsidies not at all. As the previous results confirm, forest owners vary in their knowledge, management extent and experience, as well as in their management objectives, and overall this has a significant impact on the forest owner's activities and behavior, including applying for EU funding. According to Lithuanian research in 2015, four types of forest owners are distinguished: forest ownerentrepreneur; households, family forest property; passive forest owner lover of forest environment and Ad Hoc special forest owners. (Stanislovaitis 2015). Similar results in the classification of forest owners are reported by Ficko, 2019, classifying forest owners according to their management purpose, additionally distinguishing the fifth group of forest owners as multi-purpose forest owners.

Statistics from the Rural Support Service show that forest owners have so far mostly used the measure for the support of the thinning of young stands and advanced growth, and this activity is also noted by respondents as a key priority for further EU support. A significant difference is observed regarding to forest drainage and road construction activity, which is often mentioned as the desirable priority direction for further EU support, but so far support available for this measure is utilised in small amount. Forest establishment and the purchase of small-scale machinery and motorised tools have also been mentioned as important priority directions. These activities have been the ones for which forest owners have used EU support in considerable amount so far. Similarly, there has been a growing desire by forest owners for compensation payments for the protection and management of nature values.

The results of the survey also show which stages of the EU support procedure require improvements in order to increase the number of forest owners who would be ready to apply for EU financial support and use it. In the FASC survey the main reasons were identified why forest owners had not previously applied for the EU financial support for forest management: $35 \%$ of forest owners stated that they did not have the forest stands which comply with the requirements; $24 \%$ did not use EU support due to their lack of knowledge in forest evaluation, while 24\% mentioned other reasons -e.g. at the moment the person was not the forest owner or the area was co-owned, lack of experience and inactive forest management as well as forest management only for obtaining firewood for personal use. However, 20\% stated that there was no information available about this possibility.

According to Quiroga (2018), the obstacles in applying for subsidies include bureaucracy and administrative requirements, possible changes in support policies and support measures, partial loss of control over their property and planning of management activities, and generally inflexible and restrictive forest management regimes do not compensate for the subsidies received and the opportunities these subsidies offer. In the FASC survey, 25\% of respondents who have used EU forest management support mentioned that they were satisfied with the procedure of support granting. However, $22 \%$ also indicated that the way forest owners receive information on the availability of EU financial support should be improved. Similarly, $20 \%$ indicated that the submitting procedure of the documents should be improved and the application procedure for financial assistance should be simplified.

\section{CONCLUSIONS AND DISCUSSION}

The profile of forest owners who are interested in applying for for EU financial support and who use it for forest management is the following:

(a) forest owners with more than 10 years of forest management experience;

(b) own more than 10 ha of forest;

(c) knowledgeable and informed forest holders, who have acquired education in the field of forestry or have obtained the knowledge through training.

Those forest owners who have obtained EU support are satisfied in $99 \%$ of the cases with the procedure of support granting. This is also evidenced by the fact that $94 \%$ of forest owners intend to continue applying for EU support also in the future. However, $25 \%$ of these forest owners also acknowledge that the information dissemination to forest owners on the support options could be improved. The same pertains to the document submission procedures.

Analysing the desirable EU support measures for the next programme period, the support measure for thinning and tending of young stands was prevailing. This measure is prioritized by forest owners who have already used EU support as well as those who have not used the support. However, this choice of forest owners is certainly influenced by the legislative requirement that young stands should be thinned at least once per period, for coniferous stands up to 10 years of age, and for deciduous stands up to 5 years of age. (Cabinet Regulation No. 308, 2012). Forest drainage and maintenance of road infrastructure as well as afforestation are mentioned as the next supported activities. These activities identified by forest owners are also those for which EU funding is currently available and intensively used by forest owners, with the exception of support for forest drainage and road construction, where EU support funding is available but so far has been used to a very limited extent

The forest owners who have not used EU support so far, point out the lack of information about the application options, the lack of knowledge to evaluate forest stands and prepare related documentation as important reasons for not applying. These forest owners also highly appreciate the availability of trainings and consultations regarding the next period of EU support measures, compared to those forest owners who have already used EU support.

Active transfer of information and knowledge to forest owners will significantly increase the number of forest owners applying for and obtaining EU support for forest management, thus also improving their forest management practices and the economic condition of forest stands. Active training of forest owners is also under way in other EU 
Member States, for instance in Slovenia during the period of 2015-2016, 3226 persons were trained, mainly in safe forest logging issues, but also in silviculture, NATURA 2000 issues and in the consequences of climate change. (Beguš, 2018). Therefore, the system of informing, consulting, support and training the forest owners, available in Latvia, is significant and it will raise awareness and improve knowledge of forest owners.

Acknowledgments. Thanks to the Forest Advisory Service Center of the Latvian Rural Advisory and Training Center for conducting a survey of forest owners. The research was supported by Latvia University of Life Sciences and Technologies grant 'The strengthening of scientific capacity'.

\section{REFERENCES}

1. Institure of Agricultural resources and economics (IARE), 2017. Evaluation of RDP 2014-2020 for the Extended Annual Implementation Report 2017. http://www.arei.lv/sites/arei/files/files/lapas/AIR2017_gala_20062017_LAND_www.pdf

2. Benga E. 2016. Rural Development Programme 2014-2020. Ex-post evaluation. Institute of Agricultural Resources and Economics. Available at http://www.arei.lv/sites/arei/files/files/lapas/LAP\%202007-2013\%20expost\%20nov\%C4\% 93rt\%C4\%93 jums.pdf, Latvia.

3. Beguš J. 2018. Slovenian Forest Service, A training programme on work safety for non profesional forest users, European Network for Rural Development. Available at https://enrd.ec.europa.eu/projects-practice/training-programme-work-safety-nonprofessional-forest-users en

4. Cabinet of Ministers of the Republic of Latvia, 2012. Regulations for forest regeneration, afforestation and plantation forests, No. 308.2012. Available at https://likumi.lv/doc.php?id=247349

5. Donis J. 2014. Latvian State Forest Research Institute Silava. Monitoring of private forest management, property consolidation and co-operations. Available https://www.zm.gov.lv/public/ck/files/ZM/mezhi/MAF/PARSKATS Privato mezu apsaimniekosana Silava.pdf.

6. Donis J. 2018. Latvian State Forest Research Institute Silava. Monitoring of private forest management, property consolidation and co-operations. Available at https://www.zm.gov.lv/public/ck/files/MAF2018priv_MI.pdf

7. Ficko A., Lidestav G., Ní Dhubháin Á., Karppinen H., Zivojinovic I., Westin K. 2019. European private forest owner typologies: A review of methods and use. Forest Policy and Economics, Vol. 99, pp. 21-31. https://doi.org/10.1016/j.forpol.2017.09.010.

8. Jansons J. 2010. Potential Contribution of Private Forests to the Latvian Wood Industry 2011-2015 Annual evaluation, Latvian $\begin{array}{lllll}\text { State } & \text { Forestry } & \text { Institute } & \text { Silava. } & \text { Available at }\end{array}$ http://www.silava.lv/userfiles/file/Projektu\%20parskati/2010_Jansons_Zarins_MAF.pdf

9. Ministry of Agriculture, 2015.Rural development programme (RDP) 2007.-2013. Available at https://www.zm.gov.lv/public/files/CMS Static Page Doc/00/00/00/69/57/LAP 2007-213 versija 15 clean.pdf

10. Ministry of Agriculture Latvia, 2018. Latvian Forest Sector in Facts \& Figures, 2018. Available at https://www.zm.gov.lv/public/ck/files/skaitlifakti_EN_2018web.pdf

11. Ministry of Agriculture, 2019. Rural development programme (RDP) 2014 - 2020. Available at https://www.zm.gov.lv/laukuattistiba/statiskas-lapas/2014-2020-gada-planosanas-periods-/latvijas-lauku-attistibas-programma-2014-2020-gadam?nid=2191\#jump.

12. Stanislovaitis A., Brukas V., Kavaliauskas M., Mozgeris G., 2015. Forest owner is more than her goal: a qualitative typology of Lithuanian owners. Scandinavian Journal of Forest Research, Vol, 30, Iss. 5, pp $478-491$. https://doi.org/10.1080/02827581.2014.998706

13. Quiroga S., Suarez C., Ficko A., Felician, D., Bouriaud L., Brahic E., Deuffic P., Dobsinska Z., Jarsky V., Lawrence A., Nybakk E. 2018. What influences European private forest owners' affinity for subsidies? Forest Policy and Economics, Vol. 99, pp. 136144, https://doi.org/10.1016/i.forpol.2018.08.008 